\title{
On Co-Creativity in Playful Classroom Activities
}

\author{
Alexander Schmoelz \\ University of Vienna, Austria \\ E-mail address: alexander.schmoelz@univie.ac.at
}

\section{ARTICLE INFO}

\section{Keywords:}

Creativity

Co-Creativity

Game-based learning

Gamification

Storytelling

Narrative-Socratic Dialogue

Classroom Activities

Narrative-Structural Method

\section{Article history:}

Received 24 August 2016

Received in revised form14 November 2016

Accepted 7 December 2016

ISSN: 2354-0036

DOI: 10.1515/ctra-2017-0002

\section{A B STRACT}

Recent research points to the essential role of creativity in coping with and acting in a changing world. It has been shown that individual, collaborative and communal efforts are a core capacity for acting in and coping with everchanging circumstances, such that a novel emphasis on cocreativity has arisen. Yet there is very little research on how to provide occasions for co-creativity in classrooms and so the research problem focuses on enabling co-creativity. Therefore, a playful pedagogical design was created and facilitated in classroom. The qualitative data collection methods involved narrative-Socratic dialogues with teachers and students, field notes, and gameplay videography. The Narrative-Structural Method was used to analyze the research material. The main results show that playful classroom activities provide an occasion for co-creative reframing's, engaging in dialogue, expressing emotions, and co-creating a shared story that is rich in co-determined actions. In conclusion, the pedagogical implications of the results are that classroom activities for co-creativity may facilitate mixed playful pedagogies and empty content spaces, so that children and young people can playfully identify, explore and negotiate shared topics that are novel and meaningful to themselves and others.

\section{ACKNOWLEDGMENTS}

Part of this research was carried out under the C2Learn Project - co-financed by the European Commission and the Austrian Federal Ministry for Education and Gender Equality through the Seventh Framework Programme (FP7), under grant agreement no. 318480 (November 2012 - October 2015). I am especially thankful to Thomas Weixelbaumer and 
the students of the middle school who worked on piloting the paper prototype of 4Scribes. I am very thankful to Kerry Chappell, Gertraud Kremsner, Christian Swertz, Alessandro Barberi, Matthias Huber and Wolfgang Ruge and the reviewers for taking the time to read and provide feedback on this paper. This paper is dedicated to our esteemed and much loved colleague, Professor Anna Craft, who very sadly died during this project. While we miss her companionship, we are very grateful for her kindness, inspiration and creativity.

\section{INTRODUCTION}

Scholars and scientists have identified accelerating change and uncertainty (Rogers, 1969; Giddens, 2003; Beck, 2007) as central constants in society. Some see increasing entropy (Heintz, 1982) and accelerating connectivity (Hepp, Krotz \& Winter, 2005; Seitz, 2002), others deep transformations of the way we produce as well as exchange goods, money (Teusch, 2004; Altvater \& Mahnkopf, 2007; Perraton, 1998; Neyer, 1995), and information (Feigelson, 2003; Wurzer, 2000; Featherstone \& Lash, 1995; Farhauer, 2003; Giddens, 2003) as core drivers of accelerating change, as well as the disruption of the welfare state (Bourdieu, 1997) and the politics of speed (Glezos, 2012) as a core driver of uncertainty. As a consequence of our ever-accelerating and uncertain world, Engel and Hurrelmann (1989) identify an increase in socio-psychological strain on children and young people and Wilkinson (2009) forefronts deep psychological effects such as vulnerability and anxiety.

These circumstances, coupled with the old assumption regarding radical change and society in flux (Seibt, 2016), re-raise questions for education. How can we educate and enable children and young people for a future world that we cannot fully grasp yet? How can we prepare our children for a world that is changing in such a rapid manner? There are many different answers, but two involve creativity.

One starting point for substantiating the necessity for creativity in education is the political or societal demands for certain ends or products, such as individual health (WHO, 1994), a healthy economy and a wealthy society (Craft, 2003), economic competition (Leadbeater, 2000), creative problem solving for the workforce (OECD, 2014), and creative thinking at the core of several national curricula (Ananiadou \& Claro, 2009). Here, creativity is argued as being a political or economic necessity. When it comes to education, one might decide whether to confirm or challenge these demands. Even if these demands might be highly plausible, we do not know which societal demands, knowledge, or competencies will be relevant for the uncertain future of today's children (Bloom, 1972; Maslow, 1976), and we might want to avoid entangling education in the assumed schism between the move to confirm or challenge political or economic demands. 
An alternative starting point for substantiating the necessity for creativity in education is the person, rather than the assumed societal demands of providing for an uncertain future. The kind of creativity that starts from the person is a specifically human process that shows itself "widely in the ordinary affairs of life" (Maslow, 1970, p. 160). Creativity as specifically human is evident in everyday events (Barron, 1969) and involves "the construction of personal interpretations" (Runco, 1996, p. 6). Creativity is about originality and meaningfulness (Richards, 1993) with regard to everyday problems (Ripple, 1989) rather than with regard to the high arts, science and business - an idea Craft (2001) described as "Little c Creativity". Creativity involves "personal route-finding in life“ (p. 51) and "may be helpful in looking at the education of young children" (p. 39). Here, creativity is a specifically human process that involves self-determination and the quality of personal agency (Craft, 2001; 2002; 2005; 2011). Little c Creativity is complemented by mini-c creativity (Beghetto \& Kaufmann, 2007) and modelled as a 4C approach that further involves Pro-C and Big-C creativity (Kaufmann \& Beghetto, 2009).

Research on learning and teaching ${ }^{1}$ for creativity touches on questions at the intersection of creativity and education (Cropley, 1982) and creative teaching and learning (Fryer, 1996). Learning and teaching for creativity has been investigated in different domains, such as mathematics (Mann, 2006), science (Cremin et al., 2015), and music (Burnard, 2012), in terms of levels - from early years (Woods \& Jeffrey, 1996) through to higher education (Kleiman, 2008) - as well as with an emphasis on generic (Beghetto \& Kaufmann, 2010) and inclusive approaches (Schuppener, 2005) or in the context of policy and practice (Craft, 2005). Seminal studies on creativity in education have been based on the individualistic approach to creativity (e.g. De Bono, 1976; Cropley, 1979). In recent years collaborative creativity has become more central in research on teaching (e.g. Littleton, Rojas-Drummond \& Miell, 2008). Currently, there is a novel research emphasis on co-creativity (Walsh, Craft \& Koulouris, 2014; Stenning et al., 2016; Chappell et al., forthcoming) as a process that integrates individual, collaborative as well as communal aspects of creativity. Co-Creativity is lifewide (Craft, 2005) rather than high, personal and internally judged (Runco, 1996; 2003) rather than externally evaluated, collaborative (John-Steiner, 2000) and communal (Chappell et al., 2012) rather than individual, and involving conflict (Chappell, 2008) and deviation from routine (Stenning et al., 2016) rather than flow. Yet we may lack research on how students manifest co-creativity in classroom activities and how to enable co-creativity in classroom. This study addresses the facilita-

\footnotetext{
${ }_{1}$ Here, teaching is merely understood as a complex artistry and not as a schematic-technocratic endeavour. This understanding of teaching is widely acknowledged in the realm of creativity (Cropley, 1979; Woods \& Jeffrey, 1996; Craft, 2001) as well as in the Continental European common core of ,Didaktik' and the 'transpositition didactique' (Hopmann, 2007)
} 
tion and manifestation of co-creativity in classroom activities and provides further interpretations for this research gap.

Against the backdrop of emphasis on co-creativity, the following questions arise: How can we facilitate co-creativity in schools and what might be the core pedagogic principles for enabling co-creativity in classrooms? This paper explores empirical findings derived from a case study that aimed to design and facilitate classroom activities for co-creativity with a focus on the storytelling game 4Scribes. 4Scribes is a card game through which students can generate a shared story by using different cards that show emotions, actions and different characters. The aim of the study study was to develop, action and research classroom activities and question both how students manifest co-creativity in specific classroom activities and how one might facilitate co-creativity in classroom activities.

A qualitative research design that involved narrative-Socratic dialogues with teachers and students, field notes and gameplay videography was implemented. The data were analyzed using the Narrative-Structural Method - initially proposed by Schuetze (1983). Following the articulation of the key theory, this paper will therefore outline:

- the classroom activities that were designed for the school pilot and how the design was facilitated in the classroom. The storytelling game 4Scribes, which was developed as part of the EU-FP7-Project C²Learn stands at the heart of the school pilot.

- $\quad$ research findings in terms of experiences voiced by students and teachers that helped to question how playful classroom activities might provide occasions for co-creativity.

- how these research findings entail new understandings that point to implications for pedagogy and the principles for the design of classroom activities involving co-creativity.

Before these three aspects are discussed, an understanding of co-creativity and the research methods will be presented in more detail.

\section{FROM CREATIVITY TO CO-CREATIVITY}

Stemming from the humanistic turn in the Italian Renaissance, rhetoric, poetry and art have been more frequently seen as individual, rather than divine (Hutterer, 1998, pp. 90-95.) In this humanistic sense, creativity is understood as conditio humana; as specifically human (Hutterer, 1998, p. 15) and as "a defining characteristic of essential humanness" (Maslow, 1970, p. 167). As late as the Enlightenment, the concept of creativity changed "from an emphasis on divine inspiration to an emphasis on individual creativity" (Niu \& Sternberg, 2006, p. 22). Moreover, human creativity was closely tied to creative genius and to the arts. Both Engell (1981) and Kristeller (1983) suggest that these understandings originated in the Enlightenment and held throughout the twentieth century. Even at the beginning of the 21st century some scholars mention 'romantic genius' as a core "rhetoric of creativity" (Banaji, Burn, \& Buckingham, 2006; Banaji, 2008); howev- 
er, they identify other rhetorics of creativity. Creativity as involving some kind of individual genius has been fundamentally deconstructed (e.g. Weisberg, 1993; Montouri \& Purser, 1995).

Four seminal approaches to creativity that deviate from the notion of individual genius and high creativity have come to the fore in recent decades: Contextual creativity, collaborative creativity, everyday creativity and the creativity of action. With regard to contextual creativity, studies show the social (Montouri \& Purser, 1995; Amabile, 1996) and cultural (Glăveanu, 2010a) embeddedness of creativity and illustrate the role of community and society as external evaluators of creativity (Glăveanu, 2010b). Possible ramifications of assessment might entail disabling creativity as discussed by e.g.: Amabile (1979) and Beghetto (2005) and, therefore, the evaluative part of contextual creativity might be avoided when it comes to education and pedagogy. With regard to collaborative creativity, one would neither deny the contextual relevance in creativity nor the "role of the individual mind in the creative process but (...) envisions the human mind as more social than we would normally realise" (Glăvenau, 2011, p. 480) and, therefore acknowledge that it embellishes the meso-level of creativity. It has been shown that collaborative creativity emerges in human interactions and is unpredictable, situated, contingent, interactional and equally distributed (Sawyer, 2003; Sawyer \& DeZutter, 2009). Creativity evolves as a process between and across people and as an emergent whole, which "is greater than the sum of its parts" (Sawyer, 2007, p. 7). Collaborative creativity shows in different forms of collaboration (John-Steiner, 2000) and might evolve through emotions (Vass et al., 2008), shared and personal discovery (Wix \& John-Steiner, 2008) and social participation (Fernández-Cárdenas, 2008). With regard to everyday creativity, self-actualizing creativity (Maslow, 1970), personal creativity (Runco, 1996; 2003), everyday creativity (Richards, 1993), mini-c creativity (Beghetto \& Kaufmann 2007) and Anna Craft's $(2001 ; 2002 ; 2005 ; 2011)$ conception of creativity as 'Little c creativity' (LCC) provide notions of creativity that allow us to differentiate high creativity from lifewide creativity and to see everyday experiences of children and young people as creative. "Little c creativity has been suggested to be the ordinary but lifewide attitude toward life that is driven by possibility thinking but is about acting effectively with flexibility, intelligence and novelty in the everyday rather than the extraordinary" (Craft, 2005, p. 19). Here, lifewide creativity involves possibility thinking, as transforming what is to what might be (Craft, 2014), intelligence, and novelty. Similarly to Craft, Schuetze (2001, p.138) conceptualizes "biographical creativity" as creative evolvement, which happens through getting involved in certain kinds of everyday mediums such as social relations, art, research, pedagogical work, music, business, crafts, or the family. Without the 'elitist approach' (Schuppener, 2005) of high creativity and genius, lifewide creativity can be experienced and understood 
regardless of sex, gender, privilege, cultural foreground, or 'genius'. Against the backdrop of this understanding of creativity, Craft and Schuetze implicitly challenge the understanding of high creativity that was merely pinned to the 'genius' of privileged Caucasian men. With regard to the creativity of action, LLC resonates with an attitude towards everyday acting. Unlike individual understandings of creativity that focus on thinking processes such as creative and divergent thinking (Runco et al., 2010), this notion of creativity accentuates how thinking and acting are interwoven. Joas (1996) has pinpointed the systematic evolvement and historic roots of the creativity of action. He resonates with the lifewide notion of creativity by arguing for the creative potential of every human action. Other studies have shown how creativity involves acts of resistance on the part of teachers to the undermining of the artistry of teaching by a technicist view of pedagogy (Craft, 2001) or students who imagine and enact a different type of sex education that is more relevant and meaningful to their desire for intimate relationships (Futter-Puati, 2014). This notion of creativity allows us to couple thinking and everyday acting in schools, and to see the actions of children and teachers as creative.

Alongside these seminal deviations from individual and high creativity, wise and humanizing creativity stands at the centre of how co-creativity is framed in this study. Studies on the value of wise, humanizing creativity for education suggest that creative teaching and teaching for creativity might provide occasions for co-constructive relationships and partnerships (Craft, 2005), co-creating preferable futures (Craft, 2011), independent thinking, equality through conversation and collaboration (Craft, Hall, \& Costello, 2014), journeys of becoming (Chappell, 2011), embodied dialogic generation of ideas (Chappell \& Jobbins, 2011), and quiet revolutions (Chappell et al., 2011). This approach to creativity is informed by both humanizing creativity (Chappell, 2008; Chappell, 2011) and wise, creative trusteeship (Craft, Gardner, \& Glaxton, 2008). Drawing on Chappell et al., (2012):

humanising creativity is an active process of change guided by compassion and reference to shared values. Change comes from people engaging in collaborative thinking and shared action to imaginatively develop new ideas, which are valuable to them and their community. (...) While individuals' ideas contribute to the creative process, individual advancement is not the dominant driving force behind the creativity. Communal development is equally important. This means that humanising creativity involves developing new ideas whilst empathetically negotiating others' needs, shared ownership and group identity (Chappell et al, 2012, p. 3).

Here, Chappell et al. (2012) point to notions of creativity that dissociate from individual and high creativity as humanizing creativity emphasizing change and creativity be- 
tween us. These notions accentuate co-creativity with reference to shared values, shared ownership and shared action, as well as collaborative thinking, compassion and empathy. Furthermore, the community takes centre stage, which "resonates with aspects of the creativity as socially? good discourse in that it forefronts the sense of school and wider community evident within communal activity. However, humanizing creativity is less dependent on the notion of 'good' as it acknowledges the key role of conflict and difference, the inclusion of which may not always lead to the support of a cohesive, common good" (Chappell, 2008, p. 17). Here, three aspects of community - that might be in tension with each other - are brought to the fore with regard to the humanising aspect of cocreativity: conflict; cohesion as the inclusion of difference; and the common good.

The notion of wise, creative trusteeship and wise creativity was first explored in an attempt to counter the understanding of creativity as universal and value-neutral (Craft, Gardner, \& Glaxton, 2008) as well as market-driven (Craft, 2005; 2008). Based on the critique of market-driven, universal and value-neutral creativity, Craft (2008) argues "that it is wise creativity that is needed in education. In other words, we need to ensure that our creativity involves taking appropriate actions, which recognize multiple forms of understanding and knowledge, and take account of multiple needs and perspectives" (p. 10). Chappell and Craft (2011, p. 366) state that "wise creativity attends to all those affected by creative actions, raising questions about collective responsibility and thus about the nature of 'trusteeship' in the twenty-first century, especially for professionals, teachers included". As a synthesis of both, the concept of Wise Humanizing Creativity accentuates life wide creativity as individual, collaborative and communal and as rich in values. Moreover, "wise humanizing creativity focuses on collective action rather than individual action" (Craft, 2013, p. 184). Here, collaborative, communal, and collective action is accentuated as the wise and humanizing aspect of co-creativity. These shifts from understanding creativity as individual, high and involving some kind of genius to life wide, collaborative and communal creativity that emphasizes creativity in and between us as well as creativity as thinking and acting provides a new focal point: co-creativity.

\section{CORE THEORY OF CO-CREATIVITY}

Co-creativity is life wide and wise, since it involves ethics and thinking about the consequences of everyday ideas and actions as well as humanizing, as it involves individual, collaborative and communal thinking and acting that stand counter to market-driven creativity and forefronts a dialogic generation of ideas, compassion, and reference to shared values.

This life wide, wise and humanizing understanding of co-creativity is specifically human and involves thinking and acting - thinking and acting that deviate from the routine 
(Stenning et al., 2016). Novelty evolves from disrupting and reframing established routines of thinking and acting. Disruption and reframing happens through sharing ideas and co-action. "Co-Creativity is novelty which has emerged through shared ideas and actions and which involves participants taking into account the impact of that novelty" (Walsh et al., 2014, p. 2). Co-creativity happens in and between us in a wise and humanizing manner through dialogue about shared ideas and actions as well as through negotiating the possible consequences of ideas and actions. Besides dialogue, another aspect of what happens in and between us is 'emotive lateral thinking'. Scaltsas (2016) understands emotive lateral thinking as the notion of co-creativity. Creative thinking is framed as "something new, of a novel type and desirable; whereas 'lateral' is all these, but also where the novel type is not just new but surprising, too; it has been called thinking 'out of the box'." (Scaltsas, 2016, p. 109). This kind of creative lateral thinking is related to situations and to what happens between us through our emotions. Stenning (2002), as well as Stenning and Lambalgen (2011), conclude that emotions ground abstract thinking. But how are our emotions related to situations and what happens in and between us? Scaltsas (2016) builds on Stenning's conclusion that conceptual classification is guided by emotional reactions to situations. Emotions are externally induced and are reactions to situations. Scaltsas specifies that "emotional reactions are part of the content of reasoning, rather than external to our process of reasoning" (Scaltsas, 2016, p. 113). According to this view, emotions come to be internally recognized in judgments. "A first order judgement is when an agent judges how a situation impacts on her. A second order judgement is when an agent judges how a situation impacts emotionally on another" (Scaltsas, 2016, p. 113). Emotional reactions ground our abstract thinking, but in an intentional, rather than causal way, because deliberation can be core to how our emotions influence us. The ways in which our emotions influence us and others links back into the wise, humanizing understanding of co-creativity that "recognizes emotional journeys of conflict as well as of highs and lows as the granularity in shared struggles" (Craft, 2013, p. 132). In this way, the relation between thinking, emotion and situations allows us to understand how 'in us' and 'between us' is tied together and so provides a theoretical link between co-creativity as in us and between us.

These understandings led to the following definition of co-creativity, which guides this study: Co-creativity is specifically human, life wide and happens in and between us. Co-creativity is constituted in individual, collaborative and communal thinking and action that is wise and humanizing and evolves through emotive lateral thinking, dialogue and shared actions. 
Based on this understanding of co-creativity ${ }^{2}$, the categories outlined in Chappell et. al. (2017) and Walsh, Chappell, and Craft (2017) have been extended and reformulated with regard to classroom activities:

- $\quad$ Ethics and impact: Generate, explore and enact new ideas with a valuable impact on the community, discarding other ideas that lack such potential.

- Dialogue: Pose questions, debate new ideas, find ways to negotiate conflict or to go in a different direction to others if conflict is not resolved.

- Control: Take charge of different parts of the creative process, understanding the consequences of decisions, making decisions about new ideas and taking action(s).

- Co-action: Be immersed in classroom activities. Such immersion will sometimes lead to taking risks and generating surprising individual or collaborative ideas and actions.

- Re-Framing: Use the disruptions from games to disrupt the thinking and actions of oneself and others, and so move away from established routines and patterns.

- Emotive Lateral Thinking: Express emotions and talk about how emotions have an impact on one's ideas and actions, and anticipate emotions and emotional possibilities to generate ideas. (Adapted from Chappell et. al., 2017; Walsh, Chappell \& Craft, 2017)

This definition and these categories of co-creativity allow us to question the relevance of pedagogies that aim to provide occasions for co-creativity, because they build on an understanding of creativity that is lifewide rather 'high' and quite extraordinary. Since lifewide creativity can be voiced, expressed and identified by children and young people, it provides a crucial tool for understanding co-creativity in education.

The guiding questions of this study were developed against the backdrop of this specific understanding of co-creativity and the potentials for pedagogy and designing of classroom activities. This case study aims to question how students manifest co-creativity in certain classroom activities and how students and teachers experience these classroom activities.

\section{RESEARCH METHODOLOGY}

This case study was implemented in naturalistic settings and qualitative research methods were used. The case study involved a one-week school pilot at a middle school in Vienna, Austria, with a total number of 24 students (6 female and 18 male) aged $13-14$ years.

The following design was framed for this study:

\footnotetext{
2 This understanding of co-creativity is omitted from post-humanistic theories that construct computer-human-entities (Cecchetto, 2013) as well as from understandings of co-creativity as "computational creativity" (Koukourikos, Karampiperis \& Karkaletsis, 2016), "mixed-initiative co-creativity" (Liapis, Yannakakis, Alexopoulos \& Lopes, 2016) and "human-computer co-creativity" (Kantosalo, Toivanen \& Toivanen, 2015) though appreciating the value of different understandings of co-creativity.
} 


\section{Table 1}

\section{Research Activities}

Overview \& Course of Research Activities

Research Questions

Collecting Research Material
How do students and teachers experience classroom activities?
How do students manifest cocreativity in classroom activities?
Observation

(1) Fieldnotes

(2) Videography
Narrative-Socratic

(1)Teacher Interview

(2)Student Interview

(3) Group Dialogue

Analyzing Research Material

Narrative-Structural Method

\section{Research Questions}

The case study observed classroom activities that involve the storytelling game 4Scribes and asks two questions: how do students manifest co-creativity and how do students and teachers experience these classroom activities (see Table 1). The former is more narrowly focused on co-creativity categories and allows us to reconstruct the research material alongside interview statements that point to how students were engaged in ethics and impact, dialogue, control, co-action, reframing's and emotive lateral thinking. The latter question looks more broadly at a wide-range of experiences that go beyond the preestablished framework of co-creativity.

\section{Research Methods}

In the phase of collecting research material, the personal teacher interviews were held before and after the pilot week. Group dialogues with students were held right after the gameplay sessions. The gameplay sessions were filmed to obtain additional material for analysis of group dialogues and how they referred to the gameplay session. Personal student dialogues were held after group dialogues, with students who were willing to share their experiences in a one-to-one dialogue setting. Field notes were taken throughout the whole project week.

All interviews - group dialogues, teacher dialogues, and student dialogues - were held in a narrative-Socratic manner. The narrative-Socratic dialogues held with groups of students and single students were realized as "teaching and research practice" (Stenning et al., 2016). The aim was to provide a space to reconstruct and renegotiate a shared story and shared foci. The narrative-Socratic dialogue followed 
the threefold structure of autobiographical interviews: Generative phase, immanent phase and exmanent phase.

- At the beginning of the dialogue, the narrative elements involve a generative question, so that a main narrative unfolds without interruption from the researcher. The disruption of the story line would create many difficulties (Riemann, 2003). The narrative part of the dialogue might show how students concatenate occurrences (Schuetze, 1982, p. 579) as well as how they reconstruct their story collaboratively, instead of reconstructing their life-story individually (Schuetze, 1983, p. 284).

- In the phase of asking immanent questions (Riemann, 2003, pp. 12-13), the Socratic part of the dialogue unfolds by disrupting the storyline and asking Socratic questions for clarification and probing the assumptions, implications, and evidence (Paul \& Elder, 2006).

- The immanent questions can give students the space to voice what they have been thinking while co-constructing the story and clarifying the main aspects of the story.

- The following exmanent questions (Riemann, 2003, pp. 12-13) are structured questions that allow the introduction of new topics, such as the co-creativity categories and reflection on the specific "re-framings" (Stenning et al., 2016) students find most crucial.

Besides the Socratic questions in the immanent phase of the dialogue, the Socratic part of the dialogue continues over both the immanent and exmanent phases. The immanent questions keep the students focused on revealing how their thinking proceeded, on reconstructing the story they have written and describing how they wrote it. The exmanent questions involve reflection on and negotiation of the importance of their re-framing. This points to the last part of the exmanent phase in which argumentational statements can be elicited that might include evaluations and reviews of what has been said before (Riemann, 2003).

With regard to field notes and videography, it is important to clarify that this study mainly relies on interviews as primary sources for collecting research materials, but "even studies that rely mainly on interviewing, as a data collection technique employ observational methods to note body language and other gestural cues that lend meaning to the words of the persons" (Angrosino, 2008, p. 161). Field notes are meant to provide an indepth look at how students manifest co-creativity in order to facilitate the application of the co-creativity categories by the researcher. Material that is collected in field notes and videography provides contextual information as well as body language and other gestural cues that help to identify incidents and add modes of meaning other than linguistic to the analysis. Moreover, the video material allows one to analyze which cards the students play, the concepts they use, and how they put the cards down and create the story. 
The Narrative-Structural Method was used to analyse the research material that was derived from the interviews and videography. Even though the Narrative-Structural Method was developed against the backdrop of biographical studies (Schuetze, 1983), it has long been used in other fields (Riemann, 2003). In the context of research on schooling, this method has been used in studies of teacher and student biographies and the development of identities (Boehme, 2008, p. 144). In research on creativity, the NarrativeStructural Method has been used by Schuetze (2001, pp. 138 - 146) on informants manifesting 'biographical creativity'. In this study, the Narrative-Structural Method is used to analyze stories that evolve in the storytelling game 4Scribes and in the dialogues with students and teachers rather than to analyze biographical life stories.

The core perspective of this method differentiates four elementary forms of structural processes:

- different kinds of biographical action-schemes,

- $\quad$ institutional patterns of life course (such as phenomena of life and family cycles, career patterns, etc.),

- creative metamorphoses (like the emergence and gradual - often unexpected and surprising - development of creativity), and

- $\quad$ biographical trajectories (Riemann, 2006, p. 22).

In biographies, creative metamorphosis happens through creative evolvement and transformation (Schuetze, 2001, p. 143). In classroom activities the notion of creative metamorphosis focuses on nuanced, incremental transformations of students' selfconceptions. The method was used to gain insight into how they manifest co-creativity and experience classroom activities as well as how their experiences involve nuanced creative metamorphoses.

The specific steps of the Narrative-Structural Methods were adapted and followed in analyzing the research material. Steps 1 to 5 were adapted from Jovchelovitch and Bauer (2000) and an additional step was added to provide a focus on the co-creativity categories:

1. Transcription of the verbal material.

2. Separating 'indexical' and 'non-indexical' statements. Indexical statements have a concrete reference to 'who did what, when, where, and why', while non-indexical statements go beyond the events and express values, judgments and any other form of generalized 'life wisdom'. The former are used to analyze the ordering of events, the latter to investigate statements as knowledge-analysis.

3. Reconstruct the order of events based on the indexical statements.

4. Investigate opinions, judgments, concepts, general theories and reflections of the informants based on the non-indexical statement. 
5. Clustering and comparison of co-creativity from the different informants. This might allow for identifying collective aspects of co-creativity.

6. Clustering and comparison of the different dimensions of co-creativity from the different informants. This might allow for identifying collective dimensions of co-creativity.

This procedure was used to analyze stories that evolved from the storytelling game 4Scribes and the narrative-Socratic dialogues held with students and teachers rather than to analyze biographical life stories. This difference led to some methodological transformations and implications (see Discussion).

\section{Playful Classroom Activities}

There are various examples of playful activities and using games in the classroom, some of which focus on subject specific learning (e.g Chorianopoulos \& Giannakos, 2014) or on societal challenges such as bullying (e.g. Walsh \& Schmoelz, 2016) and inclusion (e.g. Kremsner, Schmoelz, \& Proyer, forthcoming; Schmoelz et. al 2017). The playful classroom activities of this study focus on enabling co-creativity. This section outlines the distinctive features of the classroom activities in order to contextualize the findings of this article. The design of the classroom activities was framed as 'playful', which was not defined via seminal theories on play and playfulness, but rather a descriptor for specific classroom activities that involve the C2L-Storytelling game '4Scribes' and further elements that might be experienced as playful. The classroom activities were designed by the head teacher after attending several workshops on co-creativity. The teacher facilitated the design over one week in a middle school in Vienna, Austria. The pupils were around 13-14 years old. The class consisted of 24 teenagers: 18 boys and 6 girls. Each day consisted of 5 lessons, each 50 minutes long.

In this paper a specific playful design, which was created by the teacher ${ }^{3}$ of the pilot class and circled around a specific storytelling game called 4Scribes, is presented. The design involves:

- the evil emperor GOHH as a symbol for all the 'bad things' that can happen in the lifeworld of children and young people, (see Fig. 1);

- $\quad$ playing the C2L-4Scribes card game to encourage students to explore ways of engaging with problems and to find out what can be done to help themselves or others (see Fig. 2);

- $\quad$ narrative-Socratic dialogues to identify and reframe problems that they experience as relevant in their lifeworld;

- $\quad$ producing a shared outcome that makes the findings of the project week available to the wider school community, so that the students' actions have an impact (see Fig. 3).

\footnotetext{
${ }^{3}$ Special thanks go to the head teacher, Thomas Weixelbaumer, who designed and facilitated the playful classroom activities in his school.
} 
The overall playful aim was to complete the avatars to defeat $\mathrm{GOHH}$. The avatars represent the growing body of knowledge about and awareness of communal problems. $\mathrm{GOHH}$ is defeated if pupils are able to find solutions to at least some of the problems that they identified as relevant beforehand.

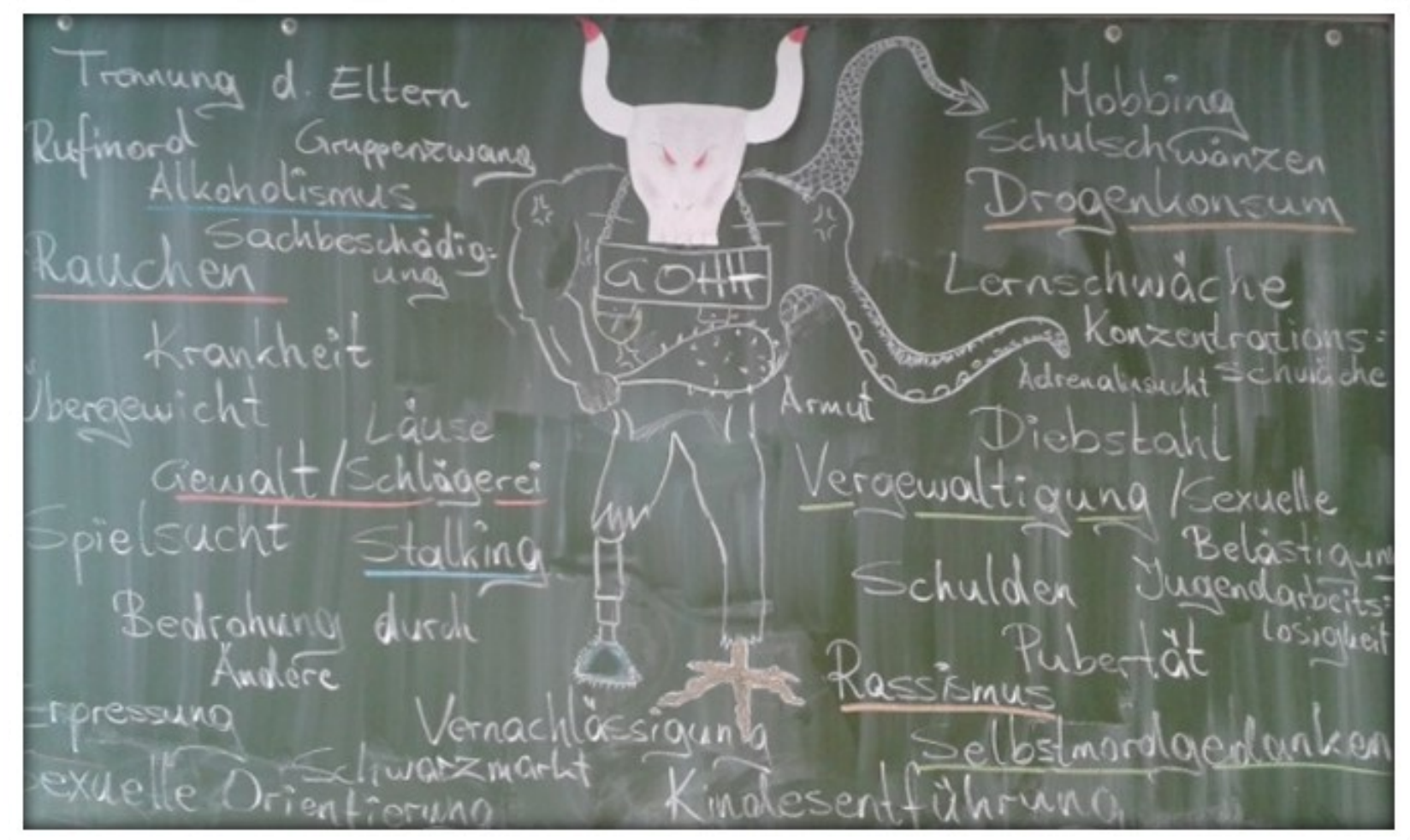

Figure 1. GOHH as a symbol for communal problems that were identified by the students.

After an introduction to the idea of $\mathrm{GOHH}$, students assembled into groups and had the opportunity to choose or create a scenario as a starting point for the CL2-4Scribes game. Playing 4Scribes was the first activity aiming to playfully identify and reframe problems that they experience as relevant. 4Scribes is a collaborative storytelling card game using cards that are designed for or by students. The objective is to tell a story collaboratively and develop ideas and preferable solutions based on the shared dilemma.

Players take turns to tell the story based on the cards in their hand. For each card, the player writes a sentence on a strip of paper. The strips and the cards are placed on the table as they are played out. In the end all cards are played and corresponding texts are written, such that a collaborative story is created by the communion of players (See Fig. 2). The students played 4Scribes twice and created two storylines. 


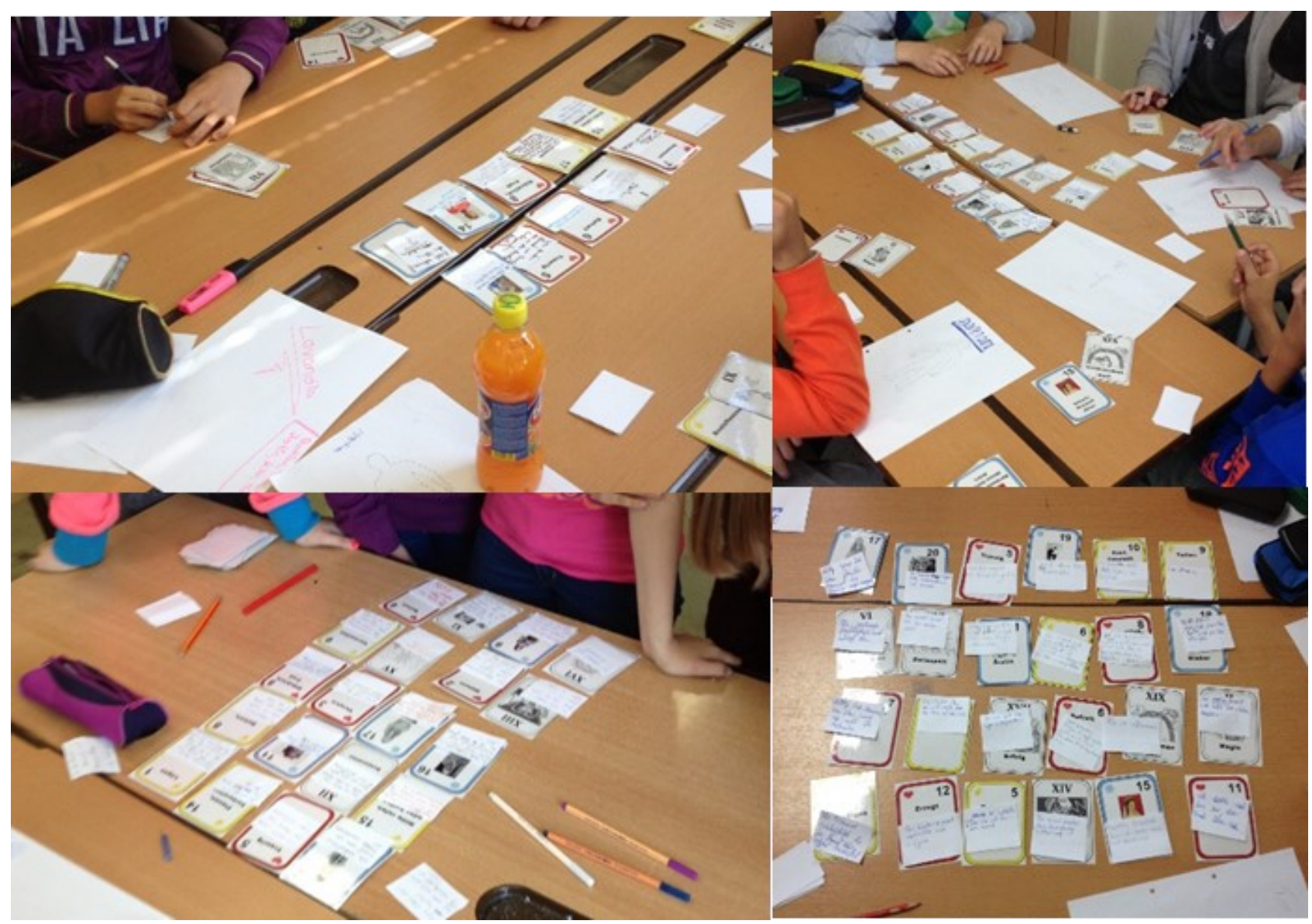

Figure 2. Collaborative story is created by the communion of players.

After playing 4Scribes, narrative-Socratic dialogues were held with students to reconstruct their shared story and identify core personal and communal problems that were attached to $\mathrm{GOHH}$ as the symbol of 'pure evil'. The following problems were identified as relevant by the students: divorce of parents, bullying or mobbing, defamation, peer pressure, cutting classes, alcoholism, drug abuse, smoking, damage to property, learning difficulties, illness, lack of concentration, poverty, being overweight, stealing, rape, sexual harassment, violence, stalking, addiction to games, unemployment, puberty, racism, suicide, extortion, neglect by parents, problems with sexual orientation, and child abduction.

After identifying their problems, the students started exploring how to engage with these problems and tried to find out what could be done to help themselves or others. The groups chose some problems that they considered most relevant:

- $\quad$ suicide and rape,,

- violence and smoking,

- drug abuse and racism,

- $\quad$ alcoholism and stalking.

Students further engaged with these problems by working on questions such as what the problem is, which forms it takes, national and international statistics concerning these 
problems, what possibilities are available for help, how one can help oneself or people that are concerned about the problem, institutions that deal with the problem, the sort of help they offer, helplines and experience reports from people that have dealt with the problem.

The students tried to find answers to some questions. They worked on one problem and each student was personally responsible for a different part of the problem and its possible solution. The results were put into a Word file and after each person in the group had finished their subchapter of the problem, they put their Word files together. All groups were able to find answers to the previously posed questions. As a last step the pupils created a brochure to present ways to engage with the identified problems and things that could be done to help themselves and others.

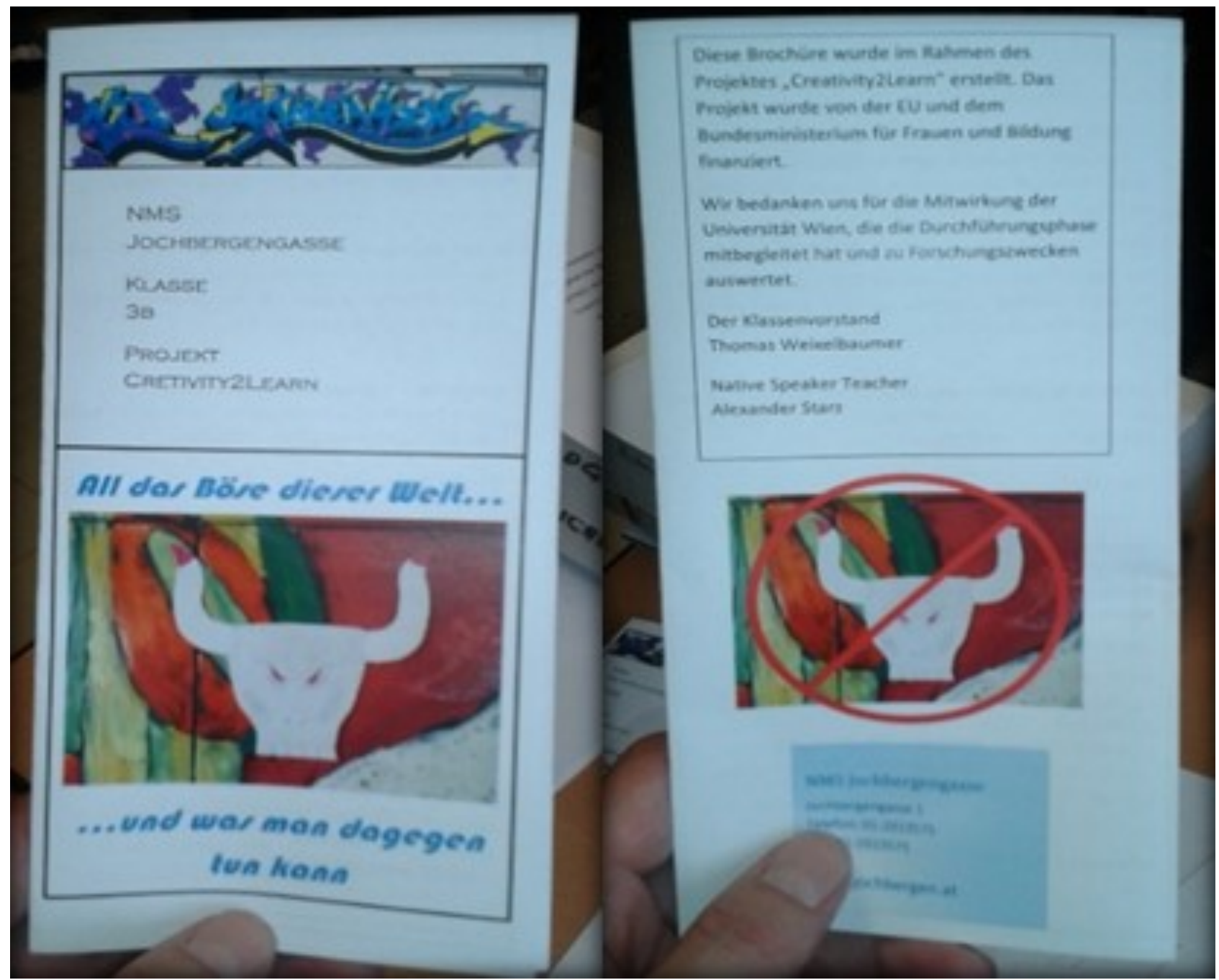

Figure 3. Shared outcome to make a difference in their community.

As a final step the brochure (Fig. 3) was delivered to their school community and posters were presented so that their personal and collaborative effort of playfully identifying and reframing problems that they experience as relevant in their life worlds, as well as exploring how to engage with these problems and trying to find out what can be done to help themselves or others, would be visible in their community, such that the students could see the impact of their ideas and actions. 


\section{FINDINGS}

Several incidents that occurred during classroom activities involving the C2Learn storytelling game 4Scribes are of interest to this study. This section outlines some findings regarding how students manifested co-creativity as well as teacher and student experiences that evolved throughout both the gameplay and the narrative-Socratic dialogues. The narrative-structural method aims to select incidents that combine 'indexical' and 'nonindexical' statements. Non-indexical statements show the values and judgments of the teachers. Indexical statements allow the ordering of events within the classroom activity that involved C2Learn 4Scribes gameplay.

On the first day of the pilot the C2Learn 4Scribes game was played by the students. The teacher stated:

Especially in the second round of gameplay, I felt that they tried to do it more and more as a group to be more satisfied with the outcome. During the first round, they were like: 'I put this card down and I don't care what the end product of our storyline will be'. At that very point, they realized that they would do something further with the story they came up with now and they would transform it into a collaborative product - then they were more motivated to produce a fun story and they were motivated to produce something that everybody would be satisfied with. So they really went into discussion mode and really tried to do it as a group. I could see that playing one more time and realizing that their story would actually be used later fostered their cooperation. (Teacher)

This statement points to incidents in "the first round", "in the second round of gameplay", and "At that very point". The researchers' observation also distinguishes between the first round and the second round:

Before the first round of the gameplay, the game was introduced and the rules were explained. In the first round of the gameplay, the students played the game to learn how the game is played. Before the second round of the gameplay, it was explained how the outcome of the gameplay tied into the classroom activities to come. (Fieldnotes)

Some components involved both non-indexical statements and indexical statements pointing to an order of events that stimulatingly involved the judgment of teachers about 'what has changed' in the second round of gameplay: 


\section{Table 2}

\section{Ordering of Events}

\begin{tabular}{ll}
\hline Indexical statements & Non-indexical statements (with some words that imply the ordering of events) \\
\hline During the first round, & $\begin{array}{l}\text { they were like: 'I put this card down } \\
\text { and I don't care what the end product of our storyline will be'. } \\
\text { they realized that they would do something further with the story they came up } \\
\text { with now } \\
\text { and the very point, } \\
\text { then they were more motivated to produce a fun story } \\
\text { and they were motivated to produce something that everybody would be satis- } \\
\text { fied with. } \\
\text { I felt that they tried to do it more and more as a group to be more satisfied with } \\
\text { the outcome. } \\
\text { In the second round of } \\
\text { ally be used later fostered their cooperation }\end{array}$ \\
\end{tabular}

This combination of indexical and non-indexical statements provides a first insight into the 4Scribes gameplay session and how the teacher experienced this classroom activity. The teacher stated that the realization of the fact that the content - which was created in the gameplay session - was going to be used in forthcoming classroom activities made the students more cooperative and motivated to produce a fun story that satisfied everybody. The field notes underline the relevance of facilitating the gameplay as an activity that is tied into other activities. One might argue that this realization was interwoven with cooperation, immersion and care of the students, as they did not care about the product and the storyline at the beginning, but then they were motivated and cooperative in creating a satisfying and shared end.

With regard to the teacher's overall judgment that the realization of the fact that the content of the story was going to be used in forthcoming classroom activities made the students more cooperative and motivated to produce a fun story that satisfied everybody, the gameplay session displayed some relevant occurrences. With regard to being cooperative, the gameplay session showed that the children worked together in an intense way:

MR: Its HO's turn.

CF: Wait here $\{\{$ looking and pointing at HO's cards $\}$ \} artist (.) inebriated (.) inebriated Here you are $\{\{$ takes a paper and pen and hands it to $\mathrm{HO}\}\}($.$) inebriated?$

MC: inebriated. What does inebriated mean?

CF: Yes, eh (.) being drunk (.) if somebody is drunk (.) Inebriated? What do I know (?) if you're not able to speak so good anymore (.) Don't you know what inebriated means? MC: No. 
CF: If somebody drinks too much. $\{$ makes a bzzss sound and wiggles her hand around\}\}

MC: Yeah, I get it. But one can also use it for example to say that the grandmother was inebriated because...

HO: I know (tone: I have an idea)

CF: Yes, because she drank sparkling wine or something...

HO: No, the grandmother cries (.) cries

CF: No but oh

HO: She has

CF: Ah she has, wait (.) The grandmother drank something. Has first

MR: ( )

CF: hmm?

CF: No the mother, ah, the grandmother was listening to Justin Bieber and was very excited. Then she took some sparkling wine and drank it.

MC: ( )

CF: Yes, just like that. She

MC: The granny started to drink and got inebriated and started to think about her son again and then she cried.

HO: How do you spell drinking?

CF: Just write drinking

MC: Or even say got drunk.

$\mathrm{HO}$ : Ok \{ \{puts the finished paper in the middle where the other final story fragments are positioned\}\}

In this intensive interaction the students show different cards to each other and ask for opinions or about what the word on the card means. They helped one another to write down their ideas, they finished the sentences of other players and agreed on shared sentences. They loudly discussed how to incorporate concepts and were able to disagree with each other, but always to find a way to go on. They were surprised and picked up ideas from others and changed their minds regarding different fragments of the sentence. At the end there was silent agreement about how to use the concept, so they all seemed satisfied with the outcome. This exemplifies how engaged the players were with the dialogue and shows that they were immersed in the gameplay. On the other hand some stated that they liked the story in the first round more than this one. This statement stands contrary to the teacher's overall judgment. In terms of co-creating a fun story, the gameplay session led to some laughter, but it came mainly from the players who were not very engaged in the gameplay. The ones who were very engaged in the gameplay took the game and the creation of a collaborative story very seriously. 
Looking at the gameplay session and at the story the students created might provide further insight into what was involved in their cooperation and dialogue, how their thinking ran, and in what specific aspects they were immersed. At the beginning, the students created a shared dilemma to start their game and story. The shared dilemma reads as follows:

Olga and Olaf are siblings and their father has just died. They don't know what to do. They are very desperate and are quarrelling with each other. (Transcript from videography of the gameplay session)

Analysis of the film material showed which cards the students played and how the dialogue evolved and their story was co-created:

\section{Table 3}

\section{Evolvement of the Storyline}

\begin{tabular}{|c|c|c|}
\hline No. & Card played /concept used & Transcript of what the students voiced as their story \\
\hline 1 & Grandmother & The grandmother was sick of all the quarrelling and interfered. \\
\hline 2 & Feeling guilty and ashamed & Olga was ashamed, but Olaf wasn't. \\
\hline 3 & Fight & $\begin{array}{l}\text { Olga und Olaf were quarrelling again and then they got into a fight with } \\
\text { each other. }\end{array}$ \\
\hline 4 & Lying & $\begin{array}{l}\text { Olaf and Olga started to lie, so that the grandmother didn't have } \\
\text { to worry any more }\end{array}$ \\
\hline 5 & Sad & The grandmother is very sad, because her son has died. \\
\hline 6 & Cooperation & Olaf and Olga tried to work together to help their grandmother. \\
\hline 7 & Justin Bieber & $\begin{array}{l}\text { They played a Justin Bieber song for their grandmother, because she } \\
\text { is a big fan. }\end{array}$ \\
\hline 8 & Suffering & $\begin{array}{l}\text { Olaf and Olga suffered because the Justin Bieber song was playing, } \\
\text { but the granny was excited. }\end{array}$ \\
\hline 9 & Inebriated & $\begin{array}{l}\text { Grandmother was listening to Justin Bieber and was very excited. } \\
\text { Then she took some sparkling wine and drank it. She got inebriated } \\
\text { and started to think about her son again and then she cried. }\end{array}$ \\
\hline 10 & Challenge & $\begin{array}{l}\text { Even if the grandmother was drunk, not thinking about her son was } \\
\text { a challenge for her. }\end{array}$ \\
\hline 11 & Demanding, begging & $\begin{array}{l}\text { The grandmother demanded that they start getting along, because her } \\
\text { nerves were at breaking point }\end{array}$ \\
\hline 12 & Discrepancy & $\begin{array}{l}\text { There was a discrepancy in their desires because they didn't know } \\
\text { whether to start getting along or not. }\end{array}$ \\
\hline 13 & Birth & Birth of more grandchildren. \\
\hline 14 & Magic & $\begin{array}{l}\text { Suddenly there was a fairy and she used magic so that Olaf and Olga } \\
\text { made up with each other. }\end{array}$ \\
\hline 15 & Light & Suddenly there was a light \\
\hline 16 & Obsessed & Olaf and Olga started to be obsessed with each other. \\
\hline 17 & Defend & $\begin{array}{l}\text { Olaf and Olga started to stand up for each other and so they grew } \\
\text { fond of each other again }\end{array}$ \\
\hline 18 & Primary school student & $\begin{array}{l}\text { After that a primary school student came by and asked how the grand- } \\
\text { mother was doing. }\end{array}$ \\
\hline 19 & Artist & One day, Olga fell in love with an artist and \\
\hline 20 & Pregnant women & became pregnant \\
\hline
\end{tabular}


At the very beginning, the grandmother is introduced: "The Grandmother was sick of all the quarrelling and interfered" (1st card, concept used: Grandmother). From that moment onwards, the grandmother was the main protagonist of the storyline (See No. 1, 4-11 \& 18). Focusing on the grandmother and her wellbeing became a shared focal point of their dialogue and cooperation. This turning point became a co-creative reframing for engaging with the dilemma at hand, because the introduction of the grandmother was novel and tangible for all group members, and they continued to refer to her throughout the story. Moreover, the reference was empathic. Here, empathy as caring about and trying to understand somebody else's feelings (No. 4, 7) and even suffering for somebody else's wellbeing (No. 8) became a further focal point of their dialogue. They were immersed in the gameplay in an empathic way. Furthermore, the story showed that conflict and difference (No. 3, 12) and cooperation (No. 6, 14, 17) were ways of engaging in the shared dilemma. Another main aspect was reference to the emotions of the protagonists. e.g. (not) being ashamed (No. 2), feeling in love (No. 19), crying (No. 9), and some moments of partnership were expressed, e.g. standing up for each other (No. 17), working together (No. 6.), making up with one another (No. 14), and fighting with each other (No. 3). It became evident that the storytelling game was providing an occasion to engage with a shared dilemma. The evolved dialogue and story included a co-creative reframing of a dilemma involving suffering to a phase of agency that involved conflict and cooperation between the suffering persons, empathy with somebody else's wellbeing, and expressing emotions.

Looking a little closer at the four elementary forms of structural processes, the game players had the protagonists show intentions and perform actions in order to overcome the death of the father. It might be seen as an incident within a biographical trajectory, as it "takes possession of everyone and hurts everyone in a very intense and consequential manner' (Riemann \& Schuetze, 1991, p. 337). Henceforth, incidents that involve activities that are voiced as being active 'for somebody or something' qualify as incidents within action schemes.

For example:

\section{Table 4}

\section{Incidents that involve actions}

\begin{tabular}{|c|c|c|}
\hline 4 & Lying & $\begin{array}{l}\text { Olaf and Olga started to lie, so that the grandmother didn't have to worry } \\
\text { any more. }\end{array}$ \\
\hline 6 & Cooperation & Olaf and Olga tried to work together to ease their grandmother's pain. \\
\hline 14 & Magic & $\begin{array}{l}\text { Suddenly there was a fairy and she used magic so that Olaf and Olga made } \\
\text { up with each other. }\end{array}$ \\
\hline
\end{tabular}


The statements (to lie, to work together) are based on certain volitions that involve an envisioned cause (so that the grandmother didn't have to worry, to help the grandmother). They are all directed towards somebody else's (the grandmother, Olaf and OIga's) wellbeing (no worries, help and making up).

Furthermore, some incidents were voiced as happening 'because of somebody or something'. In other words: happenings that are being caused by other happenings.

For example:

Table 5

Incidents that involve emotions

\begin{tabular}{lll}
5 & Sad & The grandmother is very sad, because her son has died. \\
8 & Suffering & $\begin{array}{l}\text { Olaf and Olga suffered because the Justin Bieber song was playing, but the Gran- } \\
\text { ny was excited. }\end{array}$ \\
12 & Discrepancy & $\begin{array}{l}\text { They felt a discrepancy in their desires because they didn't know whether to start } \\
\text { getting along or not. }\end{array}$ \\
\hline
\end{tabular}

These incidents were voiced by the gameplayers without specific reference to the volitions of the protagonists. The protagonists are doing or feeling something because of incidents that they involuntarily encounter. All the incidents point to emotions (sadness, suffering, feeling a discrepancy). These emotions are all caused by incidents that do not involve another person's preferences, needs, or feelings, but are self-referential (didn't know whether to get along or not) or external (son has died, song was playing). Stenning and Lambalgen (2011) suggest that situations cause emotions. These findings suggest that other people's preferences, needs and feelings are elements of situations that cause emotions.

\section{DISCUSSION}

This discussion is guided by the following questions: how do students manifest co-creativity in the context of the classroom activity involving C2Learn 4Scribes and hna and how do teachers and students experience these classroom activities? Furthermore, analysis of the material led to certain pedagogical implications for designing classroom activities that aim at co-creativity.

\section{On Co-Creativity in the Classroom}

In this case study, the classroom activity that involved C2Learn 4Scribes provided an occasion for students to write a story collaboratively. They manifested core categories of co-creativity, e.g. in terms of co-creative reframing, engaging in dialogue, expressing thinking grounded in emotions and control of the story that was established through codetermined actions. 
The introduction of the grandmother was the major disruption in the shared dilemma of suffering and the shared references to her wellbeing reframed the storyline towards ongoing action-schemes. This co-creative re-framing as disruption and deviation from routine thinking and acting (Stenning et al., 2016) further guided the students' thinking and the protagonists' actions. The co-creative reframing marks a transition from a shared dilemma of suffering to a process of agency that involved dialogue, reference to other people's wellbeing, conflict and difference, as well as emotions. In terms of the elementary forms of structural processes and judging from the overall development of the story, the death of the father hardly qualifies as an incident within a biographical trajectory as "the concept of trajectory denotes extended processes of social disorder, or, rather, the erosion of social and biographical order" (Treichel \& Schwelling, 2003). Conversely, the game players had protagonists undertake activities that helped to overcome the given dilemma, rather than stir the dilemma into an extended processes of suffering and disorder. The study suggests that co-creative reframings might play a minor role in moving from one elementary form to another and, therefore, might involve a "small, incremental personal change" (Craft, Chappell \& Walsh, 2013) in a journey of becoming (Chappell et. al., 2012) or a greater creative metamorphosis (Schuetze, 2001; Riemann, 2006). Schuetze (2001) argues that this kind of metamorphosis involves a learning process - a learning process that changes the inner and outer situation of the suffering person in a nonanticipatory manner. Creative metamorphosis might involve learning as transforming one's general conception from a conception of passive suffering (trajectories) to a conception of active agency (action schemes). For that matter, co-creative reframings might be part of a learning process that leads to or partakes in a greater creative metamorphosis as the transformation of one's own self-conception. Moreover, these co-creative re-framings of thinking patterns and small incremental changes came about through three different forms of human endeavours: dialogue, expression of emotion and emotive lateral reasoning, as well as co-determined actions towards taking control of the creative process.

The way in which the students interacted might qualify as dialogue, because it involved surprise and otherness (Buber, In Anderson \& Cissna, 1997). The players asked each other for opinions and the meaning of the cards, they supported one another in writing down ideas and disagreeing, but always went on and co-created shared sentences. The way in which the students engaged in the storytelling game emphasized verbal and non-verbal symbols and signs that were surprising to others. One might argue that the children co-created a Living Dialogic Space (Chappell \& Craft, 2011). Living Dialogic Spaces are characterized by reciprocity between the social and the spatial, in terms 
of each being constructed by the other. Embellishing Lefebvre (1991), Chappell and Craft (2011) point to the requirement of openness for core of Lived Spaces. In this study, openness is found both by providing an empty space for the students, in which vast possibilities may be explored, and the openness of the students, who show courage in occupying, filling and sharing the space with their personal and vibrant ideas and stories. The second core characteristic of Living Dialogic Spaces is dialogue in Bakhtin's (1984) and Wegerif's (2010) sense: Dialogue is shared, open-ended and goes beyond everyday conversation in a steady iteration of questions and answers that continuously create new questions. Dialogue involves listening to each other and changing one's mind, because participants tend to identify with the space of dialogue rather than with themselves. In this study, this kind of dialogue was displayed by students who had formed a sentence with the concept 'inebriated'. They shared ideas, changed their minds, listened to each other, and went beyond everyday conversation by creating a shared story with which everybody was satisfied. In contrast to Chappell's and Craft's (2011) study, in which the Living Dialogic Space was arguably produced by creative learning conversation, this study showed that the engagement in a specific storytelling game provided an occasion for creating a Living Dialogic Space. It became evident that providing an open space and putting trust in the students to co-create their own stories to address certain issues, problems, and contents in a manner that was meaningful to them, provided an occasion to co-create and occupy a shared space that became living and dialogic.

Furthermore, the players' thinking - at least their verbal representation - had the protagonists' express emotions, and these emotions further grounded the ongoing thinking processes, which points to emotive lateral thinking as a second form of human endeavor that might involve co-creative re-framings. Several incidents have shown that the players had the protagonists feel something because some other person's death or wellbeing was at stake. Here, it can be argued that the emotions grounded how the students' thinking came about and developed, because emotions and compassion were at the core of almost every part of the story. Furthermore, the findings suggest that the emotions were caused by something external to the person. These findings concur with those of Stenning and Lambalgen (2011), who showed that emotions are externally induced by situations. In this study, it was specified that other people involved in the situation seem to be the main external cause of emotions. Questions arise as to whether all people are significant, as they can induce emotions in others? This study suggests that only the emotions of people in close relationships tended to enter into the students' reasoning process. Other protagonists in the story, such as the primary school student and the other 
grandchildren, did not induce any emotions. So, significant others are people in close relationships who have the capacity to induce emotions. Other studies suggest that others become significant if the mental representation of a person activates an associated relational self, which defines who one is at that very moment (Horberg \& Chen, 2010, p. 77). Moreover, the findings showed that the emotions, which were caused by something external to the person, became internally negotiated and part of the content if the students were thinking about the protagonists' actions. The story showed that emotions became part of the content, and as the thinking evolved, the content included some actions: the protagonists felt ashamed because the grandmother was sick of their fighting, so they started to work together. The findings thus show that emotions might be externally induced by significant others, grounding our abstract thinking (Stenning, 2002) and becoming part of the content of our abstract thinking by first- or second-order judgments (Scaltsas, 2016). They also suggest that the emotive content of abstract thinking manifests in actions. It seems that emotions relate people and their mental representations to each other and contribute to what happens in and between us, both in terms of emotive lateral thinking and the emotive content of abstract thinking.

The emotive content, which was manifested in activities, involved an envisioned cause that was based on empathically negotiated preferences, such that it might be seen as co-volitional and agentic. This points to co-determined actions as a third form of human endeavor that might involve co-creative re-framings. Activities are agentic if they entail "means by which something is done or achieved" (Shogren et. al., 2015, p. 259). The protagonists took action so that the grandmother did not have to worry anymore. This implies that they could sense the grandmother's emotion, negotiate empathically, and decide that this emotion is worth attending to, as well as taking shared action to overcome the situation. Therefore, these actions might qualify as volitional, because "volition refers to making a conscious choice based upon one's preferences" (Shogren et. al., 2015 , p. 258). These actions are guided by the decision to have an impact on the grandmother's pain and help her towards wellbeing, so they are based on a certain volition that involves an envisioned cause. So the students' activities show both agentic and volitional aspects, but might not qualify as self-determined. Self-determination refers "to a quality or characteristic within a person who determines his or her own fate or course of action" (Shogren et. al., 2015, p. 252). The volition shown by students in this study is negotiated collaboratively and is a determined shared action. So the actions can be framed as co-determined, due to the fact that they are based on the shared preferences of both protagonists (co-volitional) and determine their shared actions. They are both willing 
to act on shared preferences. Their shared preferences determine their shared actions and they both want these actions to cause something. Co-determined actions are determined by shared preferences and shared volition that provide the basis for envisioning and enacting the means by which something is believed to be caused. Moreover, these co determined actions follow the same direction: they are all directed toward somebody else's wellbeing. Here, co-determined actions seem to be the core way of taking control of the creative process and are interwoven with ethics and impact. In this way, codetermined action - guided by ethics and thinking about consequences - is a concept that might allow for substantiating and differentiating the understanding of action in co-creativity.

\section{On Design Implications for Enabling Co-Creativity in Classrooms}

Finally, the implications of this study for the design of classroom activities that aim at cocreativity will be discussed. The findings indicate that the learning design of the teacher provided occasions for children to critically attend to ethical problems. It might be argued that the learning design "is ethically grounded, critical and yet humane, seeks sustainability, aligns values, shares leadership and questions purposes of creativity activity. It attends to emotions, aesthetics and multi model expression" (Craft, 2014, p. 11). The teacher's design circled around the core aspect of trying to make a serious difference to students and their community, reflecting the focus on a wise and humanizing understanding of co-creativity.

Some incidents indicated that classroom activity involving 4 Scribes is dependent on how the tool is embedded in the overall design. The study showed that when students realized that the content created in the gameplay session was linked to other classroom activities this made them more cooperative and motivated to create a story that satisfied everybody. This finding ties into research on instructional design (ID) and didactics, which points out that the design or plan of classroom activities should be separated into distinct phases and follow a certain model (Flechsig, 1991; Morrison, Ross, \& Kemp, 2001; Smith \& Ragan, 2004; Serdyukov \& Ryan, 2008). Both in ID and in this study, research indicates that the embeddedness of classroom activities is important, but the crucial difference lies in the following question: planning or designing for what? In research on ID, what is important is how performance indicators relate to specific learning outcomes. This stands in contrast to classroom activities for co-creativity, because the understanding of co-creativity as wise and humanizing is positioned against "high performance schooling" (Fielding, 2007).

The classroom activities were framed as 'playful' to highlight the focus on the specific storytelling game 4Scribes, but involved further playful elements including gamification, game-based learning, and game-based dialogues. One core aspect was gamification (Tulloch, 2014). In the context of pedagogy, this does not mean that learners are playing games. On the contrary, gamification is the introduction of game elements such as ava- 
tars, goals and progress indicators, visualization of characters, problem-solving, etc. into educational non-game experiences. On the one hand, gamification is thought to be a suitable way of improving in-class student participation and engagement (Cronk, 2012) and of increasing motivation and self-efficacy (Banfield \& Wilkerson, 2014). On the other hand, gamification has no relevant influence on learning outcomes, because "not all students will be equally inclined to take all learning activities seriously enough for their own good in meeting the learning outcome objectives" (Øhrstrøm et al., 2013, p. 422). In the classroom activities of this study the introduction of the character 'GOHH' and the avatars were elements of gamification, since they are common game elements that have been introduced into educational non-game experiences. Another viable aspect of playful classroom activities is game-based learning. Game-based learning means that students are playing games and simultaneously learning by playing. The learning process is based on the game and its inherent potential to facilitate learning (Gee, 2003). This means that pedagogies are introduced into the design and mechanics of the game itself. The educational goal and activity are incorporated into the game mechanics and learning potentially manifest in the gameplay of the students. The teachers' professional judgment ends where the kind of game is chosen, because the students are learning while playing. In the classroom activities of this study, '4Scribes' was a game-based learning activity since the learning process was an inherent potential of the game and students learned to write a shared story solely by playing the game. The third aspect is game-based dialogues (Schmoelz, 2016). Incorporating dialogues into post-game activities means that teachers need to make professional judgments about the ends for which a specific game is embedded in classroom activities. Here, the teachers can facilitate both popular games and educational games, because the dialogues that are based on previous gameplay experience are a core part of the students' learning. In the classroom activities of this study, the teaching and research method 'narrative-Socratic dialogues' was a game-based dialogue as it allowed students to reflect on, critique and renegotiate their prior gameplay experiences. These three different playful elements seem to be a crucial part of the overall design for enabling co-creativity in classrooms. The meaningful mixing of different playful pedagogic strategies is a way to encourage and engage students in co-creativity. Mixed playful pedagogies require teachers' professional judgments on a meaningful assembly of various playful elements and activities and involve gamification, game-based learning, and game-based dialogues.

Facilitating mixed playful pedagogies for co-creativity means that we might create possibilities to learn without state- or teacher-defined restrictions in terms of content and 
topics. The classroom activity that involves the storytelling game 4Scribes might be an illustrative example. In the beginning, the players were free to brainstorm the topic or problem. They described a shared topic and co-created a dilemma that functioned as a starting point of the game. Against this background, the results of the study suggest that designing classroom activities for co-creativity might involve an empty space that allows the students to brainstorm the topic and problems without initial restrictions. This empty space principle must not be confused with a space that allows for 'creatio ex nihilo' or 'creation out of nothing', because the latter understanding is strongly tied to western religious concepts of creativity and stands counter to co-creativity 'creatio in situ' or 'creation in context' (Niu, 2012). An example of 'creation in context' might be the disruption of an existing frame of thinking and acting, and further establishing co-creative reframings through dialogue, emotive lateral thinking, and co-determined actions. Moreover, even if this space is empty in terms of content, it is still rich in guidance and design of methods. So the principle might rather be termed empty content space. Empty content spaces provide occasions for enabling people to explore their ideas, establish shared problems, and co-create emotive contents and shared actions that are relevant to themselves and others. In this case study, the empty content space was structured by a classroom activity that involved a storytelling game. It provided an occasion for the children to occupy the emptiness of the content space with their vibrant and nuanced ideas. So young people could introduce the content, rather than the methods of the school pilot. Students were offered methods for constructing and re-constructing their creative expressions, they chose only the content. In the case of facilitating mixed playful pedagogies for co-creativity, it is crucial that empty content spaces are provided, that students can deliberate on their own choices of topics and problems (content) that are experienced as meaningful to themselves and others.

\section{Methodological Implications and Shortcomings}

The Narrative-Structural Method, which was originally developed to reconstruct biographical life stories (Schuetze, 1983), was adapted in order to analyze interview material regarding classroom activities and stories that evolved from a particular storytelling game. It was necessary to critically reflect on this adaption, which lead to the following methodological implications and shortcomings.

First, the Narrative-Structural Method allows one to reconstruct the ordering of events and to investigate opinions, judgments and concepts independently of whether the informants talked about their life course or about the course of the classroom activities. The perceived events and opinions and judgments about the classroom activities 
were reconstructed and investigated. This procedure enabled the coupling of certain incidents that happened in the classroom with specific opinions and judgments as well as allowing for a reconstruction of how students experienced the classroom activities and whether these experiences involved co-creativity.

Second, the analysis of interviews pointed to the life courses of the stories' protagonists and to their different forms of structural processes. The procedure allowed for understanding co-creative reframings in terms of thinking and acting by which students changed the form of the structural processes of the protagonists in their shared story. The analysis allowed for elaborating on how the students manifested co-creativity by constructing and re -constructing the protagonists' stories and their experiences in the classroom activities.

Third, the difference between creative metamorphoses and co-creative reframings was taken into account, as creative metamorphoses point to a biographical phase that transforms a person's identity, while co-creative reframings point to 'small, incremental personal changes' (Craft, Chappell, \& Walsh, 2013) that involve a disruption of established patterns of thinking and action as well as novel framings that happen dialogically and are grounded in emotion. This difference is crucial because it allows for reconstructing reframings of established patterns as incremental and nuanced changes from incidents of suffering to incidents of agency, without claiming that these changes involve biographical transformations of a persons' identity.

Fourth, in spite of the fact that the Narrative-Structural Method is based on an interactionist concept of self, it still emphasizes sequentially concatenated personal and group experiences. The focus on sequentiality and experiences involves a blind spot with regard to simultaneity, interaction and discursive practices in the process of co-creativity. Studies that have a strong focus on interactions and discursive practices have identified musing, acting out, humour and singing as characteristic of collaborative creativity and have linked collaborative and discursive features to cognitive processes (Vass, Littleton, Miell, \& Jones, 2008), the establishment of difference in classroom activities (Sturm, 2015) and belittlement as dominant discourse practices (Kremsner, Schmoelz, \& Proyer, forthcoming). Vass, Littleton, Miell, and Jones (2008) have worked with discourse analysis of social psychology, Kremsner, Schmoelz, and Proyer (forthcoming) engaged in Situational Analysis (Clarke, 2005) and Sturm (2015) used the Documentary Method. Whereas the discourse analysis of social psychology and Situations Analysis allows one to examine discursive practices, the Documentary Method "allows us to differentiate between theories, norms and intentions on the one hand and the non-intentional or habitual activities or practices on the other hand" (Bohnsack, 2010, p. 109). Focusing on discursive 
practices as well as differentiating intentional and non-intentional practices may strengthen future research on co-creativity.

\section{CONCLUSION}

It has been argued that co-creativity is wise because it involves ethics and thinking about the consequences of everyday ideas and actions, humanizing because it involves individual, collaborative and communal thinking and acting that evolves through the dialogic generation of ideas, compassion and reference to shared values, and involves co-creative reframings that stem from dialogue, emotive lateral thinking, and shared actions. Core aspects of co-creativity are ethics and impact, dialogue, taking charge, coaction, re-framing and emotive lateral thinking.

In this study, the question of how students manifest co-creativity in classroom activities and how to enable co-creativity took centre stage. Therefore, empirical research methods were implemented that involved narrative-Socratic dialogues with students and teachers as well as gameplay videography and field notes. The Narrative-Structural Method was used to analyze the given material. The analysis of the material had certain pedagogical implications for the design of classroom activities that aim at co-creativity.

The classroom activity involving the storytelling game '4Scribes' provided an occasion for students to write a story collaboratively. They manifested core aspects of cocreativity in terms of co-creative re-framings, engaging in dialogue, expressing thinking grounded in emotions, and control that was established through co-determined actions. Co-creative re-framings as a disruption and deviation from routine thinking and acting marked a transition from a shared dilemma of suffering to a process of agency that involved dialogue, reference to other people's wellbeing, conflict and difference, as well as emotions. These co-creative re-framings of thinking patterns involved small incremental changes that came about through three different forms of human endeavour: dialogue, emotive lateral reasoning, and co-determined actions. The students' dialogue, involved surprise and otherness (Buber, In Anderson \& Cissna, 1997). It was shared, open-ended, and went beyond everyday conversation through a steady iteration of questions and answers that continuously created new questions. The dialogue involved listening to each other and changing one's mind, which points to openness with one another. Therefore, the students created what Chappell and Craft (2011) call a 'Living Dialogic Space'. It became evident that the storytelling game 4Scribes provided an occasion to co-create and occupy a shared space that became living and dialogic. Further findings confirm that emotions might be externally induced by significant others, ground our abstract thinking (Stenning, 2002), and become part of the content of our abstract thinking by first- or sec- 
ond-order judgments (Scaltas, 2016). Moreover, it has been shown that this emotive content of abstract thinking manifests in actions. Emotions relate persons and their mental representations to each other and build the core component of what happens in and between us, both in terms of emotive lateral thinking and the emotive content of abstract thinking. The emotive content, which is manifested in activities, involved an envisioned cause that was based on empathically negotiated preferences, and therefore students showed co-determined actions as a third form of human endeavour that involved cocreative re-framings. Co-determined actions are different to self-determined actions (Shogren et. al., 2015), because co-determined actions are determined by shared preferences and shared volitions that provide the basis for envisioning and enacting the means by which something is believed to be caused.

The pedagogical implications of this study for designing classroom activities that aim to enable co-creativity are threefold. First, the study indicates that the classroom activity involving 4Scribes is dependent on how it is embedded in the overall design. An utmost crucial fact for student motivation is that they need to realize that the content created in one classroom activity becomes even more important in the next activity. Second, the overall design involved mixed playful pedagogies. Mixed playful pedagogies are teachers' professional judgments on a meaningful assembly of various playful elements and activities that introduce gamification, game-based learning and game-based dialogues to the classroom. The meaningful mixture of these playful pedagogies is a way to encourage and engage students in co-creativity. Third, facilitating mixed playful pedagogies for co-creativity might be coupled with empty content spaces. Empty content spaces are characterized by the absence of state- or teacher-defined content and provide occasions for enabling people to explore their ideas, establish shared problems, and cocreate emotive contents and shared actions that are relevant to themselves and others. In this case study, the empty content space provided an occasion for the children to occupy the emptiness of the content space with their vibrant and nuanced ideas.

Focusing on the sequentiality of students' experiences with the Narrative-Structural Method has been proven as a sound way to study co-creativity in the classroom; however, some methodological blind spots have been identified. Therefore, future research on co-creativity might additionally focus on simultaneity, interaction and discursive practices by using the discourse analysis of social psychology, Situation Analysis or the Documentary Method. Discourse analysis as well as Situation Analysis allows research to identify discursive practices and the Documentary Method helps to differentiate intentional and non-intentional practices. Identifying dominant discourses and non-intentional 
practices provides a basis for studying the role of co-creativity in disrupting and reframing dominant discourses and practices.

\section{REFERENCES}

Altvater, E., \& Mahnkopf, B. (1997). Grenzen der Globalisierung: Ökonomie, Ökologie und Politik in der Weltgesellschaft. Münster: Westfälisches Dampfboot.

Amabile, T. M. (1979). Effects of External Evaluation on Artistic Creativity. Journal of Personality and Social Psychology, 37 (2), 221-233.

Amabile, T. M. (1996). Creativity in context. Colorado: Westview Press.

Ananiadou, K. \& M. Claro (Eds.) (2009). 21st Century Skills and Competences for New Millennium Learners in OECD Countries. OECD Education Working Papers. No. 41, OECD Publishing. http://dx.doi.org/10.1787/218525261154

Anderson, R. \& Cissna, K. N. (1997). The Martin Buber - Carl Rogers dialogue. Albany: State University of New York Press.

Angrosino, M. (2008). Recontextualizing Observation: Ethnography, Pedagogy, and the Prospects for a Progressive Political Agenda. In N. Denzin \& Y. Lincoln (Eds.). Collecting and Interpreting Qualitative Materials. (pp. 161-183). Thousand Oaks: Sage. Bakhtin, M.M. (1984). Problems of Dostoevsky's Poetics, Edited and Translated by Caryl Emerson. Introduction by Caryl Emerson. Minneapolis: University of Michigan Press. Banaji, S. (2008). Creativity: Exploring the Rhetorics and the Realities. In R. Willett, M. Robinson, J. Marsh (Eds.), Play, Creativity and Digital Cultures. Routledge Research in Education. (pp. 147-165). Routledge: London, UK.

Banaji, S. Burn, A. \& Buckingham, D. (2006). Rhetorics of Creativity: A Review of the Literature. Arts Council England: London, UK.

Banfield, J. \& Wilkerson, B. (2014). Increasing Student Intrinsic Motivation and SelfEfficacy Through Gamification Pedagogy. Contemporary Issues In Education Research, 7 (4), 291-298.

Barron, F. (1969). Creative Person and Creative Process. New York: Holt, Rinehart \& Winston. Beck, U. (2007). Weltrisikogesellschaft. Suhrkamp Verlag: Frankfurt am Main.

Beghetto, R. (2005). Does Assessment Kill Student Creativity? The Educational Forum, 69(3), 254-263.

Beghetto, R. A., \& Kaufman, J. C. (2007). Toward a Broader Conception of Creativity:

A Case for Mini-c Creativity. Psychology of Aesthetics, Creativity, and the Arts, 1, 73-79. Beghetto R \& Kaufman, R (2010). Cultivating Creativity in the Classroom. New York: Cambridge University Press.

Bloom, B. (1972). Taxonomie von Lernzielen im Kognitiven Bereich. Weinheim und Basel: Beltz. 
Boehme, J. (2008). Qualitative Schulforschung auf Konsolidierungskurs: interdisziplinäre Spannungen und Herausforderungen. In W. Helsper \& J. Böhme (Eds.), Handbuch der Schulforschung. (pp. 125-157). Wiesbaden: VS Verlag.

Bohnsack, R. (2010). Documentary Method and Group Discussions. In R. Bohnsack, N. Pfaff, W. Weller (Eds.), Qualitative Analysis and Documentary Method in International Educational Research. Opladen: B. Budrich.

Bourdieu, P. (1997). Das Elend der Welt. Zeugnisse und Diagnosen alltäglichen Leidens an der Gesellschaft. Konstanz: Universitäts-Verlag Konstanz.

Burnard, P. (2012). Musical Creativities in Practice. Oxford: Oxford University Press.

Cecchetto, D. (2013). Humanesis. Sound and technolocial posthumanism. London: University of Minnesota Press.

Chappell, K. (2008). Towards Humanising Creativity. UNESCO Observatory E-Journal Special Issue on Creativity, Policy and Practice Discourses: Productive Tensions in the New Millennium, 1(3), 1-22.

Chappell, K. (2011). Journeys of Becoming: Humanizing Creativity. In K. Chappell, L. Rolfe, A. Craft \& V. Jobbins (Eds.), Close Encounters: Dance Partners for Creativity. (pp. 89-100). Stoke on Trent: Trentham.

Chappell, K. \& Craft, A. (2011). Creative Learning Conversations: Producing Living Dialogic Space. Educational Research, 53 (3), 363-385.

Chappell, K. \& Jobbins, V. (2011). Partnership for Creativity. Expanding Teaching Possibilities. In K. Chappell, L. Rolfe, A. Craft \& V. Jobbins (Eds). Close Encounters: Dance Partners for Creativity. (pp. 149-160). Stoke on Trent: Trentham Books.

Chappell, K., \& Craft, A., with Rolfe, L., \& Jobbins, V. (2011). Not Just Surviving but Thriving. In K. Chapell, L. Rolfe, A. Craft \& V. Jobbins (Eds.), Close Encounters: Dance Partners for Creativity. (pp. 143-159). Stoke on Trent: Trentham Books.

Chappell, K., Craft, A. R., Rolfe, L., \& Jobbins, V. (2012). Humanizing Creativity: Valuing our Journeys of Becoming. International Journal of Education \& the Arts, 13(8), 1-35. Chappell, K., Walsh, C.S., Kenny, K., Wren, H., Schmoelz, A., and Stouraitis, E. (2017). Wise Humanising Creativity: Changing How We Create in a Virtual Learning Environment. International Journal of Game-Based Learning, 7(4), (under review).

Chorianopoulos, K. \& Giannakos, M. (2014). Design Principles for Serious Video Games in Mathematics Education: From Theory to Practice. International Journal of Serious Games, 1 (3), 51-59.

Clarke, A. E. (2005). Situational Analysis. Grounded Theory after the Postmodern Turn. Thousand Oaks, London \& New Delhi: Sage. 
Craft, A. (2001). Little c Creativity. In A. Craft, B. Jeffrey, M. Leibling (Eds.), Creativity in Education. (pp. 45-61). London: Continuum.

Craft, A. (2002). Creativity and Early Years Education. London: Continuum.

Craft, A. (2003). The Limits to Creativity in Education: Dilemmas for the Educator. British Journal of Educational Studies, 51(2), 113-127.

Craft, A. (2005). Creativity in Schools. London: Routledge.

Craft, A. (2008) Trusteeship, wisdom and the creative future of education? UNESCO Observatory: Journal of Multi-Disciplinary Research in the Arts, 1(3), 1-20.

Craft, A. (2011). Creativity and Education Futures. Stoke on Trent: Trentham Books.

Craft, A. (2013). Childhood, Possibility Thinking and Wise. Humanising Educational Futures. International Journal of Educational Research, 61, 126-134.

Craft, A. (2014). Wise Humanising Creativity: A Goal for Inclusive Education. Revista Nacional e Internacioal de Educacion Inclusiva, 7(1), 3-15.

Craft, A. \& Chappell, K. (2014). Possibility Thinking and Social Change in Primary schools. Education, 3-13, 1-19.

Craft, A. \& Chappell, K. \& Walsh, C. (2013). C2Learning Design for CER. Retrieved from http://www.c2learn.eu/sites/default/files/C2Learn_D2_2_1_Learning_Design _for_CER_vf.pdf, 16.12.2014.

Craft, A., Gardner, H. \& Claxton, G. (2008). Nurturing Creativity, Wisdom, and Trusteeship in Education: A Collective Debate. In A. Craft, H. Gardner, \&G. Claxton, (Eds.) Creativity, Wisdom, and Trusteeship. Exploring the Role of Education. (pp.1-14). Thousand Oaks: Corwin Press.

Craft, A., Hall, E. \& Costello, R. (2014). Passion: Engine of Creative Teaching in an English University? Thinking Skills and Creativity, 13, 91-105.

Cremin, T., Glauert, E., Craft, A., Compton, A. \& Styliandou, F. (2015). Creative Little Scientists: Exploring Pedagogical Synergies between Inquiry-Based and Creative Approaches in Early Years Science. Education 3-13, 43(4), 404-419.

Cronk, M. (2012). Using Gamification to Increase Student Engagement and Participation in Class Discussion. In T. Amiel \& B. Wilson (Eds.), Proceedings of EdMedia: World Conference on Educational Media and Technology 2012, (pp. 311-315). Association for the Advancement of Computing in Education (AACE).

Cropley, A. (1979). Unterricht ohne Schablone. Wege zur Kreativität. Ehrenwirth: München.

Cropley, A. (1982). Kreativität und Erziehung. München: Reinhardt.

De Bono, E. (1976). Teaching thinking. London: Temple Smith.

Engel, U. \& Hurrelmann, K. (1989). Psychosoziale Belastung im Jugendalter. Berlin/New York: De Gruyter. 
Engell, J. (1981). The Creative Imagination: Enlightenment to Romanticism. Cambridge: Harvard University Press.

Farhauer, O. (2003). Qualifizierung, Betriebsspezifität und Arbeits/osigkeit. Baden-Baden: Nomos.

Featherstone, M. \& Lash, S. (1995). Globalization, Modernity and the Spatialization of Social Theory: An Introduction. In M. Featherstone, S. Lash, R. Robertson (Hg.), Global Modernities. (pp. 1-24). London/Thousand Oaks/New Delhi: Sage Publications.

Feigelson, F. (2003). Globales Dorf. Weltmarkt der Medien. In Le Monde diplomatique (Ed.), Berlin: Atlas der Globalisierung.

Fernández-Cárdenas, J. M. (2008). The situated aspect of creativity in communicative events: How do children design web pages together?. Thinking Skills and Creativity, 3(3), 203-216.

Flechsig, K.- H. (1991). Kleines Handbuch didaktischer Modelle. Göttingen: Zentrum für didaktische Studien.

Fielding, M. (2007). The Human cost and Intellectual Poverty of High Performance Schooling: Radical Philosophy, John MacMurray and the Remaking of PersonCentred Education. Journal of Education Policy, 22(4), 383-409.

Fryer, M. (1996). Creative Teaching and Learning. London: Paul Chapman.

Futter-Puati, D. (2014). 'Tap and Gap?': Possibility Thinking within Young Cook Islanders Gendered Experiences ... Dreams? Realities? Fantasy? International Conference of the Australian Association for Research in Education (AARE). Freemantle, Australia.

Gee, J. P. (2003) What Video Games Have to Teac $h$ Us About Learning and Literacy. New York: Palgrave/Macmillan.

Giddens, A. (2003). Die große Globalisierungsdebatte. In M. Kleiner, \& H. Strasser (Eds.), Globalisierungswelten. Köln: Halem. pp. 33-47.

Glăveanu, V. P. (2010a). Principles for a cultural psychology of creativity. Culture \& Psychology, 16(2), 147-163.

Glăveanu, V. P. (2010b). Creativity in Context: The Ecology of Creativity. Evaluations and Practices in an Artistic Craft. Psychological Studies, 55(4), 339-350.

Glăveanu, V. P. (2011). How are we creative together?: comparing sociocognitive and sociocultural answers. Theory \& Psychology, 21(4), 473-492.

Glezos, S. (2012). The Politics of Speed: Capitalism, The State and War in an Accelerating World. London: Routledge.

Heintz, P. (1982). Die Weltgesellschaft im Spiegel von Ereignissen. Diessenhofen: Ruegger. Hepp, A., Krotz, F., \& Winter, C. (Eds.) (2005). Globalisierung der Medienkommunikation Eine Einführung, Wiesbaden: Vs Verlag Für Sozialwissenschaften. 
Hopmann, S. (2007). Restrained Teaching: The Common Core of Didaktik. European Educational Research Journal, 2, 109-124.

Horberg, E. J. \& Chen, S. (2010). Significant Others and Contingencies of Self-Worth: Activation and Consequences of Relationship-Specific. Journal of Personality and Social, 98(1), 77-91.

Hutterer, R. (1998). Das Paradigma der Humanistische Psychologie. New York/Wien: Springer. Joas, H. (1996). The Creativity of Action. Cambridge: Polity Press.

John-Steiner, V. (2000). Creative Collaboration. New York: Oxford University Press. Jovchelovitch, S. \& Bauer, M. W. (2000). Narrative Interviewing. London: LSE Research Online. Available at: http://eprints.Ise.ac.uk/2633, originally published In: Bauer, Martin W.; Gaskell, G. (eds). Qualitative Researching with Text, Image and Sound: A Practical Handbook. London: SAGE.

Kaufmann, J. C. \& Beghetto, R. (2009). Beyond Big and Little: The Four C Model of Creativity. Review of General Psychology, 13(1), 1-12.

Kantosalo, A., Toivanen, J., \& Toivonen, H. (2015). Interaction Evaluation for HumanComputer Co-creativity: A Case Study. Proceedings of the Sixth International Conference on Computational Creativity, 276-283.

Kleiman, P. (2008). Towards Transformation: Conceptions of Creativity in Higher Education. Innovations in Education and Teaching International, 45(3), 209-217.

Kremsner, G., Schmoelz, A. \& Proyer, M. (forthcoming). Against the Rules - Disrupting and Reassessing Discursive Practices of Playfulness. International Journal of Play, (under review).

Kristeller, P. O. (1983). 'Creativity' and 'Tradition'. Journal of the History of Ideas, 44(1), 105-113. Leadbeater, C. (2000). Living on thin air: The new economy. London: Penguin.

Lefebvre, H. (1991). The Production of Space. Oxford/Cambridge, MA: Wiley-Blackwell. Liapis, A., Yannakakis, G. N., Alexopoulos, C., \& Lopes, P. (2016). Can Computers Foster Human Users' Creativity? Theory and Praxis of Mixed-Initiative Co-Creativity. Digital Culture \& Education, 8(2), 136-153.

Littleton, K., Rojas-Drummond, \& S., Miell, D. (2008). Introduction to the special issue: 'Collaborative creativity: Socio-cultural perspectives'. Thinking Skills and Creativity, 3(3), 175-176.

Mann, E. (2006). Creativity: The Essence of Mathematics. Journal for the Education of the Gifted, 30(2), 236-260.

Maslow, A. (1970). Motivation and Personality. New York: Harper Collins.

Maslow, A. (1976). The Farther Reaches of Human Nature. New York: Penguin Books. 
Montuori, A., \& Purser, R. (1995). Deconstructing the lone genius myth: Toward a contextual view of creativity. Journal of Humanistic Psychology, 35(3), 69-112.

Morrison, G. R., Ross, S. M., \& Kemp, J. E. (2001). Designing Effective Instruction. New York: John Wiley.

Neyer, J. (1995). Globaler Markt und territorialer Staat. Zeitschrift für Internationale Beziehungen, 2, 197-215.

Nui, W. (2012). Confucian Ideology and Creativity. The Journal of Creative Behavior, $46(4), 274-284$.

Niu, W. \& Sternberg, R. J. (2006). The Philosophical Roots of Western and Eastern Conceptions of Creativity. Journal of Theoretical and Philosophical Psychology, 26, 18-38.

OECD (2014) PISA 2012 Results: Creative Problem Solving: Students' Skills in Tackling Real-Life Problems (Volume V), Pisa: OECD Publishing

Øhrstrøm, P., Sandborg-Petersen, U., Thorvaldsen, S. and Ploug, T. (2013). Teaching Logic through Web-Based and Gamified Quizzing of Formal Arguments. In D. Hernández-Leo, T. Ley, R. Klamma \& A. Harrer (Eds.), Scaling up Learning for Sustained Impact. Springer, Berlin, Heidelberg, pp. 410-423.

Koukourikos, A., Karampiperis, P., Karkaletsis, V. (2016). Creative stories: Modelling the principal components of human creativity over texts in a storytelling game. Digital Culture \& Education, 8(2), 118-135.

Paul, R. \& Elder. L. (2006). The Thinker's Guide to the Art of Socratic Questioning. Dillon Beach: Foundation for Critical Thinking.

Perraton, J. et al. (1998). Die Globalisierung der Wirtschaft. In U. Beck (Ed.), Politik der Globalisierung. Frankfurt am Main: Suhrkamp. pp. 134-168.

Richards, R. (1990). Everyday creativity, eminent creativity, and health. Creativity Research Journal, 3, 300-326.

Riemann, G. (2003). A Joint Project Against the Backdrop of a Research Tradition: An Introduction into "Doing Biographical Research". Forum Qualitative Sozialforschung/Forum: Qualitative Social Research, 4(3). Retrieved from http:// www.qualitative-research.net/index.php/fqs/article/view/666/1440.

Riemann, G. (2006). An Introduction to "Doing Biographical Research". Historical Social Research 31(3), 6-28. URN: http://nbn-resolving.de/urn:nbn:de:0168-ssoar-29937.

Riemann, G. \& Schuetze, F. (1991). "Trajectory" as a Basic Theoretical Concept for Analyzing Suffering and Disorderly Social Processes. In D.R. Maines (Ed.), Social Organization and Social Process: Essays in Honor of Anselm Strauss. (pp. 333-357). New York: de Gruyter. 
Ripple, R. (1989). Ordinary Creativity. Contemporary Educational Psychology, 14, 189-202.

Rogers, C. R. (1969). Freedom to Learn. Columbus: Merril Publishing.

Runco, M. A. (1996). Personal Creativity: Definition and Developmental Issues. New Directions in Child Development, 72, 1-30.

Runco, M. A. (2003). Education for Creative Potential. Scandinavian Journal of Educational Research, 47(3), 317-324.

Runco, M. A., Millar, G., Acar, S., \& Cramond, B. (2010). Torrance Tests of Creative Thinking as Predictors of Personal and Public Achievement: A Fifty Year Follow-Up. Creativity Research Journal, 22(4), 361-368.

Sawyer, R. K. (2003). Group creativity: Music, theater, collaboration. Mahwah: Erlbaum.

Sawyer, K. (2007). Group genius. New York: Basic Books.

Sawyer, R. K. \& DeZutter, S. (2009). Distributed creativity: How collective creations emerge from collaboration. Psychology of Aesthetics, Creativity, and the Arts, 3(2), 81-92.

Scaltsas, T. (2016). Brainmining emotive lateral solutions. Digital Culture \& Education, 8(2), 106-18.

Schmoelz, A. (2016). Ernsthafte Spiele als Anlass für Ko-Kreativität? In J. Haag, J. WeiBenböck, W. Gruber, \& C.F. Freisleben-Teuscher (Eds.), Game Based Learning. Dialogorientierung \& spielerisches Lernen analog und digital. (pp. 107-118). Brunn am Gebirge: IKON.

Schmoelz, A., at all (2017). Inklusiver Unterricht mit Digitalen Spielen. Medienimpulse. Beiträge zur Medienpädagogik, 2. (In Print).

Schuetze, F. (1982). Narrative Repräsentation kollektiver Schicksalsbetroffenheit. In E. Lämmert (Ed.), Erzählforschung. (pp. 568-590). Stuttgart: Metzler.

Schuetze, F. (1983). Biographieforschung und narratives Interview. Neue Praxis, 3, 283-293.

Schuetze, F. (2001). Ein biographieanalytischer Beitrag zum Verständnis von kreativen Veränderungsprozessen: die Kategorie der Wandlung. In R. Burkholz, Ch. Gärtner \& F. Zehentreiter (Eds.), Materialität des Geistes. Zur Sache Kultur - Im Diskurs mit Ulrich Oevermann. (pp. 137-162). Weilerswist: Velbrück-Verlag.

Serdyukov, P. \& Ryan, M. (2008). Writing Effective Lesson Plans: The 5-Star Approach. Boston: Pearson Allyn and Bacon.

Seibt, J. (2016). Process Philosophy. Edward N. Zalta (Ed.), The Stanford Encyclopedia of Philosophy, retrieved from http://plato.stanford.edu/archives/spr2016/entries/ process-philosophy.

Seitz, K. (2002). Bildung in der Weltgesellschaft, Frankfurt am Main: Brandes \& Apsel. 
Shogren, K. A., Wehmeyer, M. L., Palmer, S. B., Forber-Pratt, A.J, Little, T.J., \& Lopez, S. (2015). Causal Agency Theory: Reconceptualizing a Functional Model of Self-Determination. Education and Training in Autism and Developmental Disabilities, 50(3), 251-263.

Smith, P. L. \& Ragan, T. J. (2004). Instructional Design (3rd Ed.). Danvers, MA: John Wiley \& Sons.

Stenning, K. (2002). Seeing Reason: Image and Language in Learning to Think. Oxford: Oxford University Press.

Stenning, K. \& Lambalgen, M. (2011). Reasoning, Logic and Psychology. Wiley Interdisciplinary Reviews. Cognitive Science, 2, 555-567.

Stenning, K., et all, (2016). Socratic dialogue as a teaching and research method for cocreativity? Digital Culture \& Education, 8(2), 154-68.

Schuppener, S. (2005). Selbstkonzept und Kreativität von Menschen mit Behinderung. Bad Heilbrunn: Klinkhardt.

Sturm, T. (2015). Herstellung und Bearbeitung von Differenz im inklusiven Unterricht. Rekonstruktion mit Hilfe der dokumentarischen Videointerpretation. In. R. Bohnsack, B. Fritzsche, \& M. Wagner-Willi (Eds.) Dokumentarische Video- und Filminterpretation. (pp. 131-152). Opladen: Barbara Budrich.

Teusch, U. (2004). Was ist Globalisierung? Ein Überblick: Darmstadt.

Treichel, B., \& Schwelling, B. (2003). Extended Processes of Biographical Suffering and the Allusive Expression of Deceit in an Autobiographical Narrative Interview with a Female Migrant Worker in Germany. Forum Qualitative Sozialforschung/ Forum: Qualitative Social Research, 4(3). Retrieved from http://www.qualitativeresearch.net/index.php/fqs/article/view/672/1452

Tulloch, R. (2014). Reconceptualising Gamification: Play and Pedagogy. Digital Culture \& Education 6(4), 317-333.

Vass, E., Littleton, K., Miell, D., \& Jones, A. (2008). The discourse of collaborative creative writing: Peer collaboration as a context for mutual inspiration. Thinking Skills and Creativity, 3(3), 192-202.

Walsh, C.S. \& Schmoelz, A. (2016). Pre-Service Teachers Designing Digital Games to Make a Serious Difference in Classrooms. International Conference of the Australian Association for Research in Education (AARE). Freemantle, Australia.

Walsh, C. S.; Chappell, K. \& Craft, A. (2017). A co-creativity theoretical framework to foster and evaluate the presence of wise humanising creativity in virtual learning environments (VLEs). Thinking Skills and Creativity, 24, 228-241. DOI: 10.1016/ j.tsc.2017.01.001. 
Walsh, C.S., Craft, \& A., Koulouris (2014). Gameful Learning Design to Foster CoCreativity? International Conference of the Australian Association for Research in Education (AARE). Freemantle, Australia.

Wegerif, R. (2010). Mind Expanding: Teaching for Thinking and Creativity in Primary Education. Maidenhead: Open University Press.

Weisberg, R. (1993). Creativity. Beyond the Myth of Genius. New York: Freeman and Company.

Wilkinson, I. M. (2009). Risk Vulnerability and Everyday Life. The New Sociology. Routledge: Taylor \& Francis Group.

Wix, L. \& John-Steiner, V. (2008). Peer inquiry: Discovering what you know through dialogue. Thinking Skills and Creativity, 3(3), 217-225.

Woods, P. \& Jeffrey, B. (1996). Teachable Moments: The Art of Creative Teaching in Primary School. Buckingham: Open University Press.

World Health Organisation (1994). Life Skills Education for Children and Adolescents in Schools. Geneva: WHO.

Würzer, J. (2000). Atemlos. Die virtuelle Welt des Internet-Kapitalismus. Stuttgart: Stuttgart München DVA.

Corresponding author at: Alexander Schmoelz, University of Vienna, Austria, Department of Education, Sensengasse 3a, A-1090 Vienna.

E-mail: alexander.schmoelz@univie.ac.at 